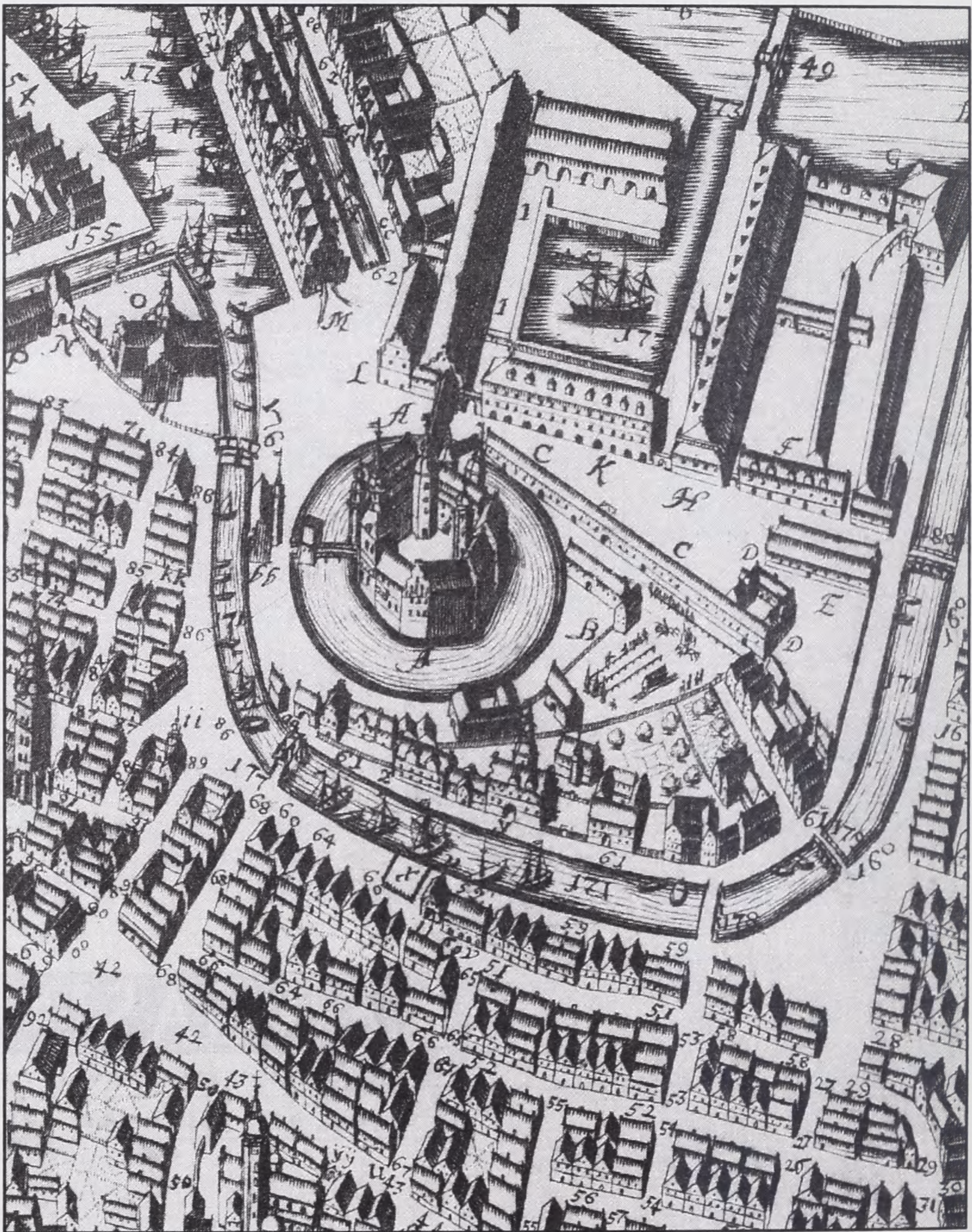

Udsnit af Johan Husmans stik af Kobenhavn 1674 på grundlag af Peder Resens Atlas. Øverst ses havnen - den nuvarende bibliotekshave. 


\section{Det Kongelige Biblioteks have}

af landskabsarkitekt, lektor, dr.agro. Malene Hauxner

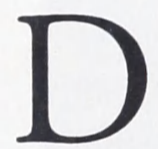
et Kongelige Biblioteks bygning er stor, tung og monumental. Med murværk af røde sten, vedbendbeklædning, granitsokler, tårne med spir og balkoner og rundbuede vinduesfag giver den et middelalderligt indtryk. Bygningen ligger blandt ligeværdige: proviantgården, rigsarkivet og det mægtige tøjhus med ubrudt facade og tag af røde teglsten. Tilsammen tegner disse bygninger konturen af et stort rektangulært rum, hvor biblioteket indskyder sin ene halvdel. I dette primære rum er opstået et sekundært, kvadratisk, hvis vægge dannes af to bygninger i gule sten, forbundet af en mur med tre indgangsportaler, af en paradisæbleallé foran en lav rødstensstøttemur med åbning foran bygningens indgang, af en høj rødstensmur med en lille bygnings takkede gavl på midten og af en lindearkade, hvis stammer forsvinder $i$ en hæk af avnbøg. Rummet mellem rektanglet og det indlagte kvadrat er blevet til gårde og gader - selve kvadratet til den have, det følgende skal handle om.

Grusede havegange, der fører fra bibliotekets fremtrukne indgangsparti mellem tårnene mod den midterste portal i muren mellem de to pavilloner og fra proviantgårdens frontespice mod den lille bygning bag muren foran tøjhuset, tegner i plan et ganske let drejet kors, der opdeler kvadratet i fire græsklædte felter. Midt i korset og som en spejling af biblioteksfacadens fremspring ligger et kvadratisk bassin kantet af gule klinker. Bassinets hjørner er konkavt afrundet, så der opstår en ottekantet figur. Græsfelternes indre konturer er tegnet af rette og buede linier. Anlæggets symmetri er understreget af fire søjlebaser, busketter og gamle lamper i hjørnerne og bøgehække og rosenrabatter langs kanterne. To grupper af birketræer i tætte klumper af rhododendron er på planen også del af denne symmetri.

Havens værdi ligger først og fremmest i det rumlige - i det store rektangulære rum der giver dimension og betydning og i det mindre, kvadratiske der skaber beskyttelse mod vind og støj.

Ud over de rumlige kvaliteter er det frodigheden, blomsterrigdommen, fuglelivet, sollyset, den flimrende skygge, bænkene og græsset til at ligge på, der i mere end en forstand gør stedet til en paradisisk have. Men noget skurrer - en voldsom kamp mellem forskellige intentioner.

Man får lyst til at få klarhed over, hvordan haven er blevet til for måske derigennem at forstå, hvorfor den ser ud som den gør.

$\mathrm{P}$ å Peder Resens luftperspektiv af København Hafnia 1674 kan man mellem tøjhuset, proviantgården, rigsarkivet, det daværende kongelige bibliotek og et bådehus, som biblioteket nu er bygget ovenpå, se et næsten kvadratisk havnebassin. Tøjhushavnen, som 
det blev kaldt, var havn for krigsskibe, som kunne lægge til for at proviantere og blive forsynet med våben. Mens det var Christian IV, der havde fàet havn og bygninger opført i årene mellem 1598 og 1604, var det Frederik IIIs fortjeneste, at der i 1665 blev bygget et kongeligt bibliotek og kunstkammer.

Af Geddes kvartersplan fra 1757 fremgår det, at der er kommet flere bygninger til langs havnebassinet. Samtidigt viser den, at Nicolai Eigtveds Christiansborg er blevet bygget i mellemtiden. Tegninger af maleren Christian Hetsch, der iøvrigt blev gift med datteren af proviantforvalteren Stephan Peder Nyeland, fortæller os, at der i midten af 1800-tallet mellem disse bygninger var såkaldte vandporte, bueformede åbninger i murede porte, hvorigennem varerne kunne føres ud til skibene. I 1860erne blev havnen opgivet som flådestation og havnebassinet efterhånden fyldt op. Der blev i stedet bygget geværfabrik, smedie og bolig til rustmesteren. Arealet lå efter sigende hen i en yderst forsømt tilstand, men ifølge fotos var der ganske charmerende med græs, selvtrådte stier og forvildet bevoksning fra tidligere haver.

Samtidig med opfyldningen var Frederik IIIs bibliotek og kunstkammer blevet for småt og brandfaren for overhængende, hvorfor overbibliotekaren foreslog, at der blev bygget et nyt. I 1879 blev der nedsat en kommission, der sammen med arkitekt, professor Hans J. Holm skulle programmere et nyt bibliotek. I 1883 udkom betænkningen, der imidlertid ikke sagde noget om, hvor biblioteket skulle ligge. I 1887 blev bibliotekets nuværende placering udpeget. I 1895 forelå det endelige forslag til lov om biblioteket og i 1897 blev loven vedtaget.

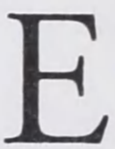

n perspektivtegning, gengivet $\mathrm{i}$ Architekten 18/1900 illustrerer Hans J. Holms forestilling om et haveanlæg foran biblioteksbygningens facade, der i denne udgave kun har en enkelt port i midten og tre vinduesfag på hver side af tårnene. De to pavilloner er kortere, står tættere på hinanden og er forbundet med en mur med en enkelt portal i midten. Haven er gennemskåret af et kors af gange, der mødes i en cirkulær plads med et lille bassin i midten. Mod biblioteket udvider den ene gang sig til en halvcirkulær plads. Lave plantninger indrammer de fire græsfelter. Buskadser i hjørnerne og træer ved bygningernes gavle støtter symmetrien. Der er ikke her tale om et rum i rummet, men om ét stort, hvor bygningernes facader danner vægge - uden de senere tilkomne lunde, alléer og mure. Artiklen i Architekten er endvidere forsynet med en plan af de eksisterende forhold, men ikke med en haveplan. En perspektiv af facaden mod havnen viser, at der bag høje smedejernsgitre var tænkt buske og træer i et mindre haveanlæg.

\section{I landskabsgartner Edvard} Glæsels arkiv på Danmarks Veterinærog Jordbrugsbibliotek findes en udateret, farvelagt kalke, en haveplan i mål $1: 1200$, der svarer meget godt til Holms perspektiv. Vi kan genkende den halvcirkelformede plads foran bibliotekets ene indgang, den cirkulære plads med 


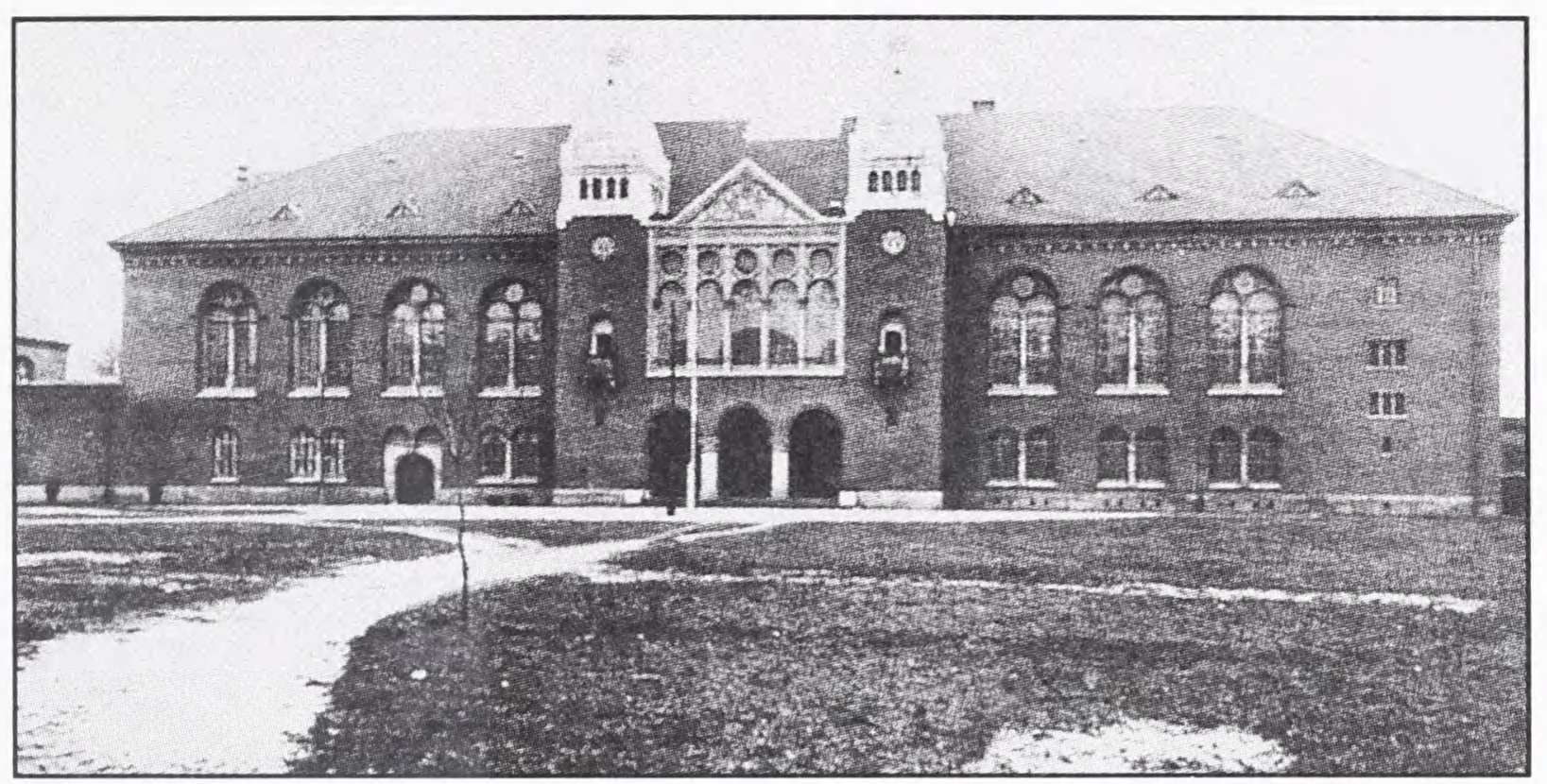

Det nyåbnede bibliotek, ca. 1906.

det lille bassin i midten, det korsformede gangsystem og græsplænerne med kantplantningerne. Helt ens er de dog ikke. Holms tegning har ikke Glæsels diagonallagte stier og små søjletræer i kanten.

Edvard Glæsel var en velrenommeret landskabsgartner af den gamle skole, som Holm havde arbejdet sammen med før. De havde tegnet Vestre Kirkegård, der var færdiganlagt i 1892.

Det var da også Glæsel, der kom til at tegne haveanlægget mod Christiansgade, nu Christians Brygge, og de fine broderiparterrer i bibliotekets to lysgårde, man dengang kunne se ned på fra de store vinduer. I hans arkiv findes tegninger, der svarer til planer og fotografier bragt i Architekten 13/1906. Af skitser kan vi se, at han har forsøgt sig med mange varianter af de to lysgårde. Typen, hvor et diagonalt kors af gange, en cirkulær plads i midten og kanter af lave planter omkring græsfelter samt hjørner markeret af små søjleplanter, er tilbagevendende. Det ender dog med at blive til en makadamiseret vej i kanten og et rektangulært parterre i midten.

Det tog sin tid at få hele anlægget færdiggjort - først i 1910 blev arealet omkring det tidligere bådehus færdiggjort. Holms konduktør Johannes Magdahl-Nielsen sagde god for en beplantning af hovedsagelig stedsegrønt omkring en statue. I fl. en samtidig opmåling er en del træer bevaret; syren, hyld, valnød og pære.

I 1906 stod Det Kongelige Biblioteks bygning færdig. Bøgerne var flyttet fra deres tidligere residens, Frederik III's bibliotek og kunstkammer på små tipvogne, der kørte på skinner på en træbro.

Biblioteket blev indviet under stor festivitas og ved kongens medvirken. I den anledning var der blevet ryddet nødtørftigt op på pladsen foran 


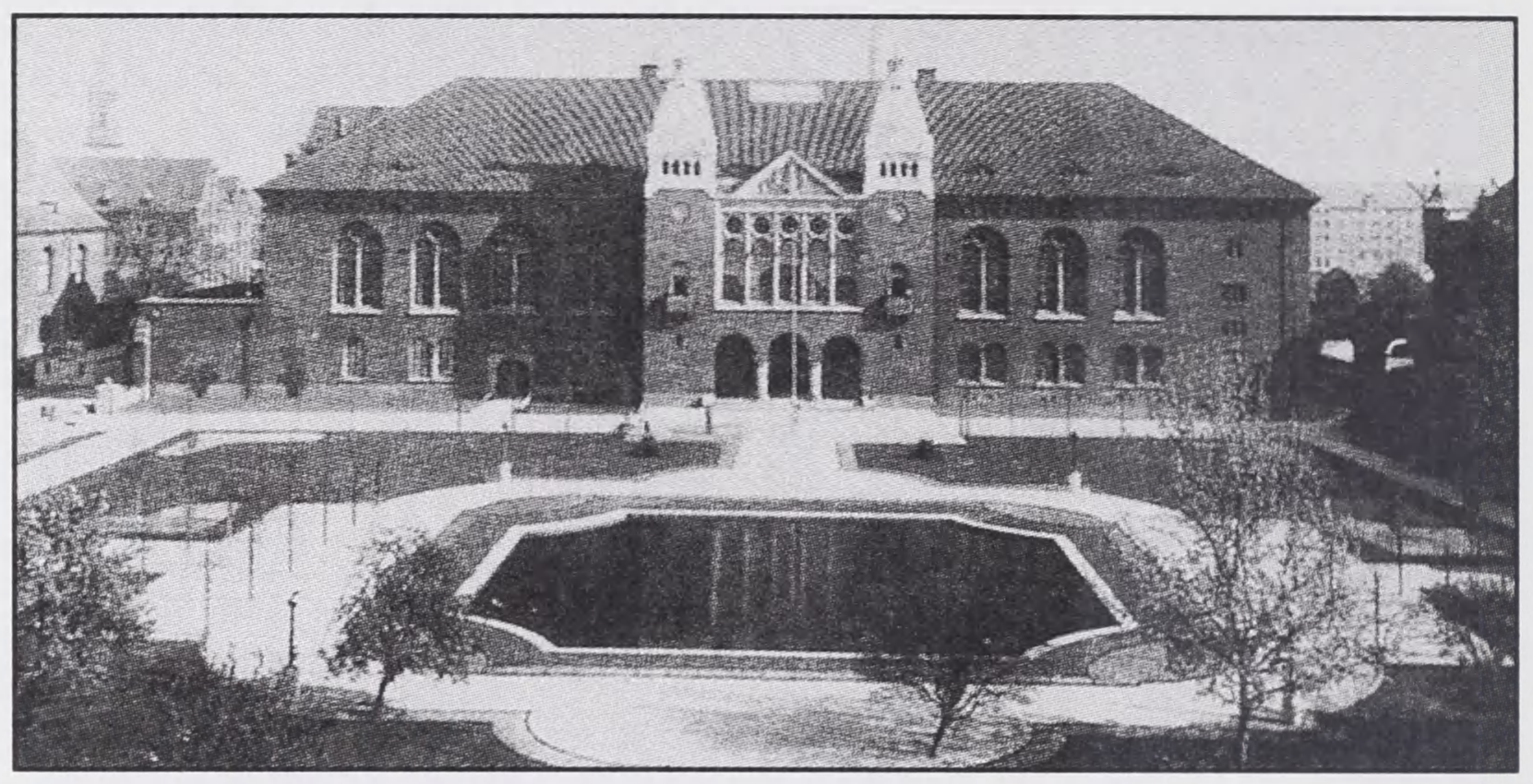

Den nyplantede have, ca. 1916.

huset og etableret en midlertidig kørevej, der sluttede i en halvcirkelformet plads foran indgangen. Man havde vaklet lidt frem og tilbage $i$ beslutningen om hvor vidt indgangen skulle ligge her eller mod havnen. Det blev til den indadvendte indgang, men nogen plads eller have var det ikke blevet til.

For oprydningen og etableringen af denne midlertidige indkørsel stod I.P. Andersen, en anlægsgartner, der i 1905 havde etableret egen virksomhed. I fl. korrespondance kan vi se, at han i 1907 bad Holm om betaling for dette udførte arbejde, for han havde "så sandt at sige hairdt brug for pengene. "I.P.

Andersen fungerede både som entreprenør og rådgiver, hvad der var ganske almindeligt på landskabsgartneriets tid. Siden 1902 havde han endvidere været ansat på Glæsels tegnestue. Han har formodentlig reelt overtaget Glæsels arbejde, efter at denne blev syg omkring 1904. Formelt overtog han hans virksomhed i 1915, da Glæsel døde.
I I.P. Andersens arkiv på Danmarks Veterinær- og Jordbrugsbibliotek findes tre forslag til haven fra henholdsvis 1912,1914 og 1915.

Forslag I, dateret 1912 minder en del om Holms og Glæsels. Haven er stadig korsdelt, der er lave plantninger omkring græsplænerne og symmetrisk anbragte buskadser og bassinet har sin barokke form med kantede og bugtede konturer. Men den cirkulære plads i midten er blevet ottekantet og der er kommet to havegange til, formodentlig, fordi der nu er to indgange mellem pavillonerne. Planen svarer næsten til en perspektiv, hvor det midterste areal er forsænket. Trapper, flankeret af store træer fører ned til pladsen omkring det lille bassin. Hvor korset ender ser man nogle buede portbygninger.

I forslag II, dateret 1914, er der tilføjet en trærække mod proviantgården og en kvadratisk figur som kunne være et bassin. Det har de senere tilkomne konkavt rundede hjørner, men 
desuden en konveks afslutning på bassinet svarende til den foran biblioteket.

Hovedformen er rektangulær som i forslag I og to havegange fører, som i det foregående, forbi bassinet. De seks græsfelter er afsluttet med buskadser i hjørnerne.

Forslag III, dateret 1915, påstemplet I.P. Andersen, landskabsgartner, Uraniavej 5 svarer stort set til det udførte. Nu er alléen og lundene kommet til og bassinet har fået sin endelige form. Der findes flere forskellige udgaver af dette forslag, tegnet lidt forskelligt. En perspektiv i tusch signeret I.P. Andersen viser det store bassin svarende til facadepartiet, fire søjletræer der korresponderer med tårnene og fire nåletræer, der yderligere understreger symmetrien. Endvidere ser man de regelmæssigt placerede birketræer.

En koteplanskitse viser indtegnede eksisterende træer, to lind, en kvæde, en liguster, en rødtjørn og en pære. Af en planteplan på kraftigt papir kan man se, at paradisæblealléen følger bibliotekets geometri mens et plantebed følger murens. I bedet er der Syringa chinensis rubra, Cotoneaster horizontalis, Forsythia, Philadelphus, Viburnum opulus, Spiræa, Weigela, Rhus cotinus, guldregn, Kerria og Ribes. Foran de to pavilloner er der foreslået Spiræa thunbergii og Spiræa arguta, hyld, Berberis og Cotoneaster, men ingen stauder. Der er sat to magnolier på plænen og Spiræa vanhouttii i de tre hjørner.

Mod tøjhusmuren er der Cotoneaster, Spiæa arguta, Spiræa thunbergii, Mahonia, Daphne og Berberis. Birkene er placeret regelmæssigt, syste- matisk og symmetrisk.

Overslaget på det udførte arbejde lød i 1915 på 28.702 kr. I I.P. Andersens arkiv findes også et tryk af en tegning benævnt 'Bygningsforandringer paa Bibliothekspladsen' underskrevet af MagdahlNielsen og Thorvald Jørgensen. Det viser en opstalt af de symmetrisk anbragte pavilloner kædet sammen af en mur med tre portaler, hvor der ovenover står: Chr. 4 1603, Chr. 91867 og Chr. 101915.

I samlingen af arkitekturtegninger, Kunstakademiets bibliotek findes to farvelagte tegninger af haven, en plan og en perspektiv, begge udaterede men signeret af Magdahl-Nielsen og Thorvald Jørgensen. Planen svarer nogenlunde til det udførte og til I.P. Andersens andre planer fra 1915, perpektivtegningen viser imidlertid et andet forslag. Bassinet ser større ud, der er ingen allé, træerne mod biblioteksfacaden er ikke klippet i arkadeform men fritvoksende og i stedet for de to birkelunde er der nogle spredte træer. Afskærmningen mod biblioteket er buet og ikke firkantet og muren mod tøjhuset ser ikke ud til at være der. I De kongelige Slotte og Havers arkiv findes et tryk af en haveplan, dateret 1916, signeret Thorvald Jørgensen. I tidsskriftet Havekunst 1923 er bragt en plan der nogenlunde svarer til denne og til den der har begge arkitekters signatur samt til I.P. Andersens forslag fra 1915.

Foreningen til Hovedstadens Forskønnelse ser ud til at have haft en vis indflydelse på tilblivelsen af bibliotekshaven. På dens foranledning udar- 


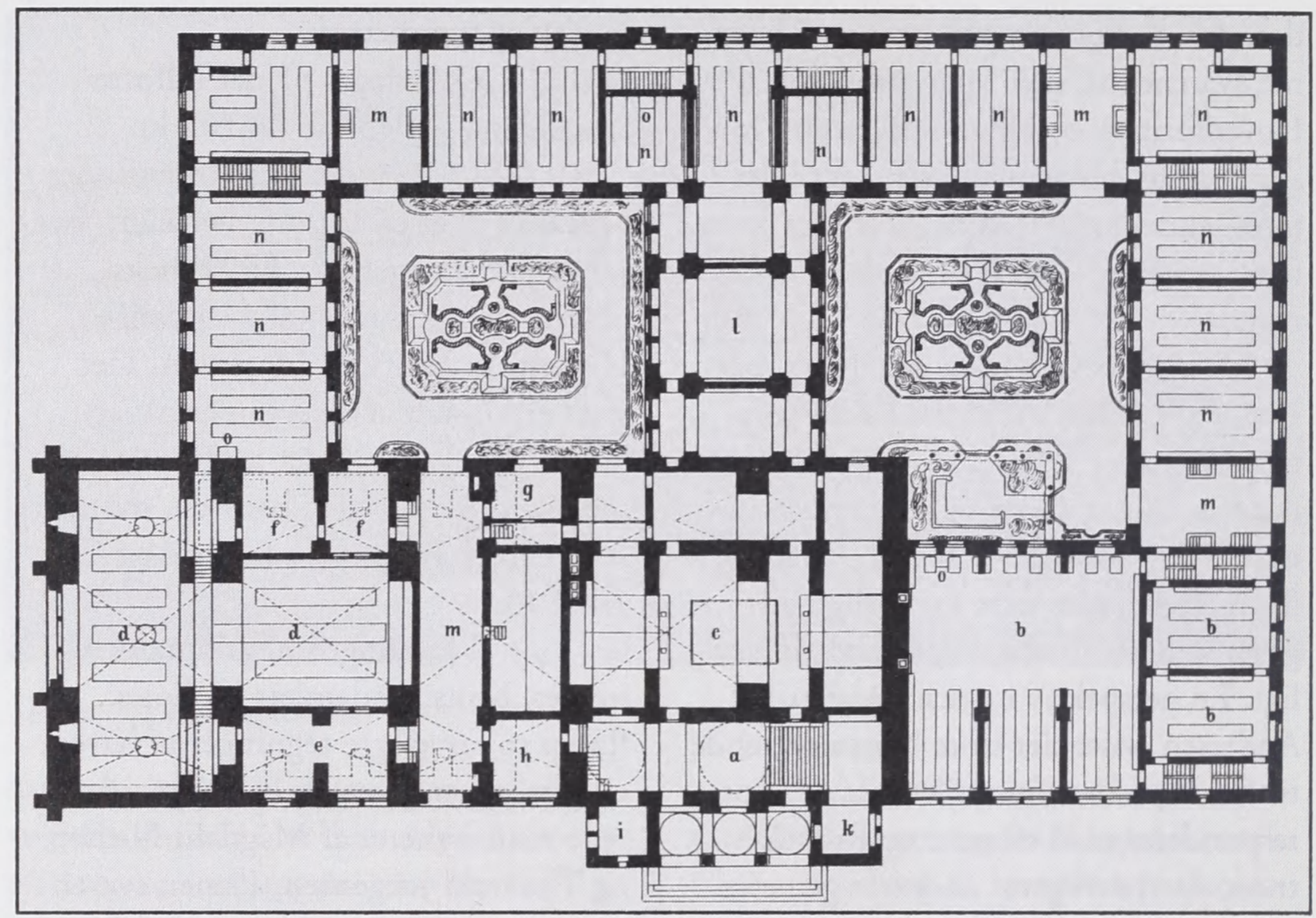

Plan af biblioteket med de to indre gairde.

bejdede Martin Nyrop i 1892 en helhedsplan for Slotsholmen, der først og fremmest drejede sig om at få ordnet de trafikale forhold. På hans plan er Frederik III's bibliotek revet ned så man fra et nyt Christiansborg kan se ind over en foreslået bibliotekshave. På det nedrevne biblioteks plads er placeret to pavilloner forbundet af en række træer. Foran biblioteket, trukket lidt tilbage, ses en åben plads med et rektangulært bassin flankeret af to felter af græs, indrammet af trærækker.

Et nyt Christiansborg som Nyrop havde foreslået var undervejs. I 1887, det år bibliotekets placering blev fastlagt, var der blevet afholdt en totrins idékonkurrence, da det andet C.F. Hansens Christiansborg var brændt i 1884.
Martin Borch og Ferdinand MeldahlAlbert Jensen fik hver en førstepræmie. I deres forslag til andet trin skulle der ligge et nyt bibliotek på bryghusets plads og rigsarkivet flytte ind i proviantgården. I stedet for det nedrevne bibliotek var der kommet væksthuse, der skilte kavalergården fra et haveanlæg. Det bestod af en allé langs tøjhuset og et parterreanlæg med tilhørende bassin i midten samt fire mindre, korsformede anlæg i hjørnerne. Det var vist første gang man her på stedet blev præsenteret for en have, der dog ikke havde tilknytning til biblioteket. Den anden ligeledes todelte idekonkurrence om Christiansborg slot, afholdt i 1904, vandt Andreas Clemmensen, Martin Nyrop og Thorvald Jørgensen. Det endte med at blive 
Thorvald Jørgensen, der blev valgt som arkitekt for byggeriet af Christiansborg. Foreningen til Hovedstadens Forskønnelse havde under Thorvald Jørgensens formandskab i 1913 foreslået, at der blev gjort noget ved bibliotekspladsen. Thorvald Jørgensen var blevet formand i 1912, samme år som hans svoger Magdahl-Nielsen var blevet $\mathrm{kgl}$. bygningsinspektør og året efter at han selv var blevet udnævint til kgl. Bygningsinspektør. Begge havde de haft tæt tilknytning til Hans J. Holm, der døde i 1916, Thorvald Jørgensen som Holms konduktør på Overformynderiet og Magdahl-Nielsen som hans tegner og konduktør på biblioteket.

Thorvald Jørgensen og Johannes Magdahl-Nielsen modtog i 1923 Foreningen til Hovedstadens Forskønnelses æresmedaille for året 1922, for projektering af bibliotekshaven.

Slotsarkitekten bliver da også i diverse leksika udpeget som bibliotekshavens arkitekt.

\section{Kunsthistorikeren Hakon} Lund tillægger ham ikke helt den rolle. "Thorvald Jorgensen, hvis indsats gik ud på at fordele rester fra det Christiansborg han havde brudt ned, opstillede fire sojlebaser i havens hjorner ... "Hakon Lund: Slotsholmen, Kbh. For og nu - og aldrig, 1987 s. 264-65.

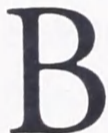

ibliotekshaven er udtænkt i en overgangstid mellem 1888 og 1916, hvor den formelle, arkitek toniske Arts and Crafts have blev anset for at være den moderne afløser af landskabsgartneriets victorianske klunkehave. Man kan i bibliotekshaven således aflæse firsernes have, hvor barokkens bugtede og kantede konturer stadig havde frit spil inden for en ortogonal geometri og en symmetrisk komposition, uafhængig af huset, hvor bunden var af grus, træerne eksotiske og de franske bede tilplantet med sommerblomster og sukkulenter. Men man kan også se 1910ernes genopdagelse af den tidlige renæssancehaves syntaks, hvor havens plan skulle spejle huset, og hvor ubehandlede mure, natursten, spejlbassiner, hjemlige frugttræer, stauder og søjletræer indgik $i$ en nøje fastlagt ortogonal geometri med forbillede i den islamiske forestilling om paradiset som en have gennemskåret af et kors.

Klunkehavens idealer kan vi se i Berlin, i arbejder af Joseph Lenné og Friedrich Schinkel. Stadsgartner Erwin Barths Savigny, Karolinger, Mierendorph og Gustav Adolphs Platz fra omkring 1912 har trods moderne programmer lignende træk. I København kan vi studere fænomenet i Glyptotekshaven fra 1906 og i anlægget foran Hirschsprungs museum fra 1911. I USA blev stilarten dyrket i City beautiful bevægelsen langt op i det 20. århundrede under betegnelsen Beaux-Art.

De danske arkitekter har kunnet hente inspiration i bøger som Gustav Meyer: Lehrbuch der Schönen Gartenkunst 1860, Édouard André: L'Art des Jardin 1879 og H. Jäger: Der Hausgarten 1880 og Gartenkunst und Gärten sonst und jetzt 1888 .

Den formelle haves idealer kan vi finde i bøger som Reginald Blomfield: The Formal Garden in England 1892, Thomas H. Mawson: The Art and 
Craft of Garden Making 1900, Paul Schultze-Naumburg: Kulturarbeiten II, Gärten 1902, Hermann Muthesius: Das Englische Haus 1904, M. Hugh Baillie Scott: Houses and Gardens 1912, Gertrude Jekyll and Sir Lawrence Weaver: Gardens for small Country Houses 1912, Lawrence Weaver: The Houses and Gardens by E.L. Lutyens 1913 og Leberecht Migge: Die Gartenkultur des 20. Jahrhunderts 1913.

Man kan endelig i bibliotekshaven aflæse brud og bånd mellem generationer - mellem arkitekterne Hans J. Holm og Thorvald Jørgensen/Magdahl Nielsen, og mellem landskabsgartnerne Edvard Glæsel og I.P. Andersen. Det var også i den tid, hvor det nære parløb mellem arkitekt og landskabsgartner blev søgt erstattet med arkitekten som ansvarlig for et gesamtkunstværk.

Havearkitekten Erik ErstadJørgensen var en af dem, der kæmpede mod denne udvikling.

I sin anmeldelse af bibliotekshaven i tidsskriftet Havekunst 1923 fremhrvede han den bygningsmæssige del af haven - den smukke havemur mellem de to, kønne lyse huse.

"Helt så heldig kan man derimod ikke sige, det mere plan-og havemassige er klaret; man marker både her og der, at forfatterne har varet udenfor deres egentlige fag, uden erfaring og uden tilstrakkelig faglig indsigt. Rent planmassigt set er der noget hojst ubehageligt ved den måde fardselen er ledet. Kommende fra rigsdagsgården krydser man på skrå mellem pillerne under rigsarkivet, hvorfra en fliserakke forer gennem den midterste del af de tre portåbninger $i$ havemuren... Midt for ligger imidlertid det store firkantede bassin, der nodvendiggor en omvej i rette vinkler; og ligesom for udtrykkelig at ville fremhave fejlen er der lagt en enkelt fliserakke midt ad den brede grusvej - noget der $i$ sig selv er alt andet end smukt - ... Havde det mon ikke varet naturligere at lede fardselen ud til siderne på strakningen mellem rigsarkivet og havemuren for derefter at kunne fortsatte ubrudt langs bassinets sider? Det store bassin $i$ havens midte er nemlig i sig selv en så god ide, at man nodig vilde se det borte; men her gor et andet fejlgreb sig geldende, idet bassinet utvivlsomt er lagt for hojt. Det ser ud til og er vist også nok tilfaldet, at alle gangene stiger op mod bassinet, at hele haven med andre ord hvalver opad $i$ stedet for det eneste rimelige, der vilde have varet at forme et terran som dette konkav, skailformet.. Selv uden bassin vilde alt tale for at forme terranet mellem disse mure konkavt, men naar dertil kommer en vandflade $i$ midten, er et fald herimod så selvfolgeligt, at man ikke forstair, hvad der kan have bevaget arkitekterne til at lagge bassinet hojt og lade terranet falde bort fra vandfladen. Den dybdevirkning, der er et bassins mest fremtradende rumlige vardi, ophaves desuden ganske og aldeles ved en sådan anbringelse. Jeg skal ikke opholde mig ved de stygge bassinkanter af gule, hårde klinker, hvor stenfliser vilde have varet langt at foretrakke, eller ved de umotiverede afskaringer $i$ bassinets hjorner, men kun endnu sige et par ord om plantevalget, hvor det ojensynlig $i$ mindst lige så hoj grad har skortet på erfaring og dybere forståelse. For det forste er her sik- 
kert alt for mange uensartede elementer sammenbragt på en forholdsvis lille plads: Her en aunbogehak, der en stammehak af lind, her roser, der stauder, her stenbrakkant og hist buksbom, og så disse meningslose busketter, der er lige uheldige, enten de er enkle, kun bestående af spirca van Houttii med et par guldregn, eller de er sammensat efter den kendte planteskolerecept: 100 buske i 50 sorter med syrener, buddleya, spirca, kerria og alt muligt blandet $i$ en ganske karakterlos masse.... Krogne frugttrasstammer og -grene passer godt ind i omgivelserne, men det samme kan ubetinget ikke siges om birk, af hvilke der ikke desmindre er to lunde pà sarlig fremtradende plads. Er der noget birk ikke egner sig til, er det da at plantes som her, regelmassigt fordelt foran en brudt hakkelinie. Deres virkemåde er slet ikke 'arkitektonisk', men 'malerisk', deres charme er den 'voksede' karakter, ikke den 'plantede'....

Heldigvis eller desvarre, alt eftersom det ses fra et almindeligt eller et specielt fagligt synspunkt, er det således, at gronne planer med hvide birkestammer, roser og stauder altid har noget bestikkende ved sig og navnlig da, nair det bydes os inde midt $i$ byen, hvor savnet af natur og planteliv er så levende. Derfor omtales bibliothekshaven ogsa altid $i$ de mest rosende vendinger; derfor blev Forskonnelsesforeningens nye medaille forleden dag overrakt de to ophavsmand, noget der for så vidt var berrettiget nok, nair henses til det fortjenstfulde $i$ af kaos at have skabt et sa tiltalende interior som dette; men for dog at hjalpe med til en udvikling på havekunstens område kan narvarende tidsskrift ikke godt omtale denne have, uden at påpege den dilettantisme, hvorom så meget $i$ bibliothekshaven desvarre barer vidne." Erik Erstad-Jørgensen: Bibliothekshaven, Havekunst 1923 s. 37-43.

\section{Haven i fremtiden}

$\mathrm{M}$ an må nok medgive ErstadJørgensen hans kritik. Haven er ikke noget kunstværk.

Måske havde man været bedre tjent med Holms og Glæsels victorianske parterrehave med de store bygninger som vægge. Men den ville nok have savnet den nuværende haves hygge. Hyggen kunne til gengæld være opretholdt $\mathrm{i}$ en rigtig Arts and Crafts have, som vi kender den fra England. Måske ville det allerbedste have været, om der stadig var et kvadratisk havnebassin, hvis tilstedeværelse Holm selv må have savnet i fl. en artikel skrevet til Berlinske Tidende.

„Saa langt ude i terranet (fra

Frederik VII's statue og til den nye Bros Ende (Tietgens) er der godt og vel 1/2 Fjerdingvej) og saa langt ned $i$ Tiden (fra 1606 til 1908 er der 300 Aar) satte denne Havn sine Spor. Men hvor er Havnen henne? Hvor er Vandet?" Hans J. Holm: Slotsholmen, Architekten 17/1908 s. 200-203.

Problemerne er mange i dag. Det asfalterede areal foran facaden, fyldt med huller og biler afskærer bygningen fra haven. Planterne er blevet gamle. De giver sure hjørner og dyb skygge over siddepladserne og skjuler såvel det lille som det store rums vægge. Man kan ikke komme til bassinet. Vandet er stillestående, det er hverken et havnebassin eller et islamisk springvand. Rosenbedene er nu fyldt med duftløse, orange sorter. Et Københavnerfortov - to rækker 
fliser med chaussésten imellem, forstyrrer forestillingen om en have. De epigonagtige, hvide bænke, de gule bassinkanter, de komiske søjlebaser, der fungerer som plantekasser, og de fire grimme lamper forlener haven med et skær af kitsch.

Nu da biblioteket endnu engang er flyttet burde man måske i den næste 10 -års periode overveje en fornyelse af haven - holde fast i de varige,

Litteratur

Andersen, I.P.: Haveanlagene ved Bispebjerg Hospital, Havekunst 1921 s. 94-97

Asmussen, Otto: Bibliotekshaven på Slotsholmen Hovedstadens nyeste parkanlag Forskønnelsen $1 / 1923$ s. $1-4$

Asmussen, Otto: Generalforsamlingen den 19. Marts 1923, Forskønnelsen 1/1923 s. 2930

Elgstrøm, Kell: Det Kgl. Bibliotek - et hus på Slotsholmen, 1993

Erstad-Jørgensen, Erik: Bibliothekshaven, Havekunst 1923 s. $37-43$ rumlige værdier og skippe de fejltagelser, der er gjort gennem tiden, såvel som dem der lå indbygget i de oprindelige forslag. Man bør i respekt for at vi i dag hverken lever på Chr. IV's tid eller i 1880 erne give haven nyt liv. At tilføre sin egen tids sprog til tidligere værkers, så der bliver en samtale ud af det, er et stort problem, hvis løsning man til stadighed må arbejde på.

Det store Kgl. Bibliotheks nye Bygning. Meddelelser fra Akademisk Architekt Forening 18/ 1900 s. $209-217$

Det Kgl. Biblioteks ny Bygning. Architekten Meddelelser fra Akademisk Architektforening 13/1906 s. 117-130

Hauxner, Malene: Fantasiens Have, 1993

Holm, Hans J.: Slotsholmen Architekten 17/ 1908 s. $200-203$

Lund, Hakon: Slotsholmen, Kbh. for og $n u$ - og aldrig, Bind I red. af Bo Bramsen, 1987

Weilbach Dansk Kunstnerleksikon, 1994

Aakjær, Svend, Mogens Lebech og Otto Norn Kobenhavn For og $\mathrm{Nu}$, Bind I, 1949 